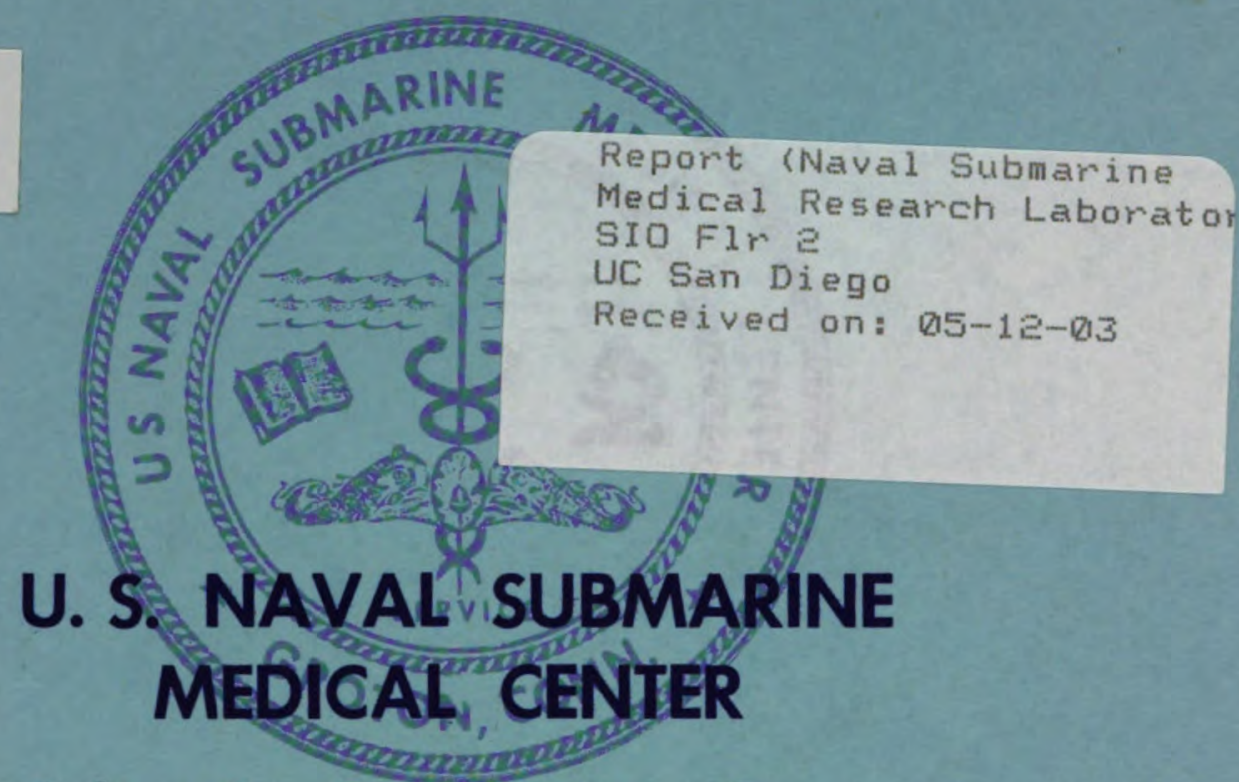

Submarine Base, Groton, Conn.

\author{
REPORT NUMBER 518 \\ BREATHING OF PRESSURE OXYGENATED FLUIDS BY SUB- \\ MERGED MAMMALS: A LITERATURE REVIEW \\ by \\ P. L. Hendricks \\ LT MC USNR

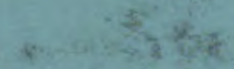

Bureau of Medicine and Surgery, Navy Department Research Work Unit MF022.03.03-9025.28

Released by:

SIO Flr irald J. Duffner, CAPT MC USN

$5 I 0$

1

RE28846

MMANDING OFFICER

v. 518

\title{
March 1968
}

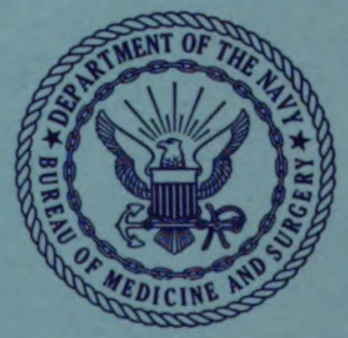

